\title{
Studies of different feed combination of growth performance in Sahiwal cows
}

\author{
Nilesh S. Mawal, S.D. Chavan and M.S. Mahalle
}

\begin{abstract}
The experiment entitled studies of different feed combination of growth performance in sahiwal cows was conducted for period of 95 day. Six sahiwal cows were divided into three groups on the nearness of age and weight. Three feeding treatment were studied namely $\mathrm{T}_{1}$ (Jowar straw adlib $+5 \mathrm{~kg}$ Green Hy. napier $+1 \mathrm{~kg}$ concentrate $), \mathrm{T}_{2}(50 \%$ Jowar straw adlib $+50 \%$ Soybean straw adlib $+5 \mathrm{~kg}$ Green Hy. Napier $+0.750 \mathrm{~kg}$ concentrate), $\mathrm{T}_{3}$ (Soybean straw adlib $+5 \mathrm{~kg}$ Green Hy.Napier $+0.500 \mathrm{~kg}$ concentrate) was fulfill requirement of sahiwal cow in all treatments. Experimental feeding lasted 95 days including 7 days gap for reducing residual effect before starting second and third period. The Growth performance of cow on jowar and soybean straw feeding was judged on the basis of body weight gain in body measurement and intake of nutrients per kg gain. Growth rate was higher in cows feed combination of jowar and soybean straw than sole feed of jowar and soybean straw was found economical for gain in weight in sahiwal cows. The per kg gain of body weight was higher in $\mathrm{T}_{2}$ treatment. It was over experimental result, the treatment $\mathrm{T}_{2}$ showed better and desirable result as compared with $\mathrm{T}_{1}, \mathrm{~T}_{3}$ treatment.
\end{abstract}

KEY WORDS : Jowar straw, Soybean straw, Concentrate, Sahiwal cows

How TO CITE THIS PAPER : Mawal, Nilesh S., Chavan, S.D. and Mahalle, M.S. (2019). Studies of different feed combination of growth performance in Sahiwal cows. Res. J. Animal Hus. \& Dairy Sci., 10(2) : 43-47 : DOI: 10.15740/HAS/RJAHDS/10.2/43-47. Copyright@ 2019: Hind Agri-Horticultural Society.

Address for correspondence :

Nilesh S. Mawal, Department of Animal Husbandry and Dairy Science, Post Graduate Institute, Dr. Panjabrao Deshmukh Krishi Vidyapeeth, Akola (M.S.) India

Email : nileshmawal123@gmail.com

Associated Authors' :

S.D. Chavan and M.S. Mahalle, Department of Animal Husbandry and Dairy Science, Post Graduate Institute, Dr. Panjabrao Deshmukh Krishi Vidyapeeth, Akola (M.S.) India 